\title{
Differential Effect of the Route of Inoculation of Rabies Virus on NeuN Immunoreactivity in the Cerebral Cortex of Mice
}

\author{
Efecto Diferencial de la Vía de Inoculación del Virus de la Rabia sobre \\ la Inmunorreactividad de NeuN en la Corteza Cerebral de Ratones
}

\author{
Aura Caterine Rengifo*; Vanessa Jazmin Umbarila*; Mary Janeth Garzón* \& Orlando Torres-Fernández*
}

RENGIFO, A. C.; UMBARILA, V. J.; GARZÓN, M. J. \& TORRES-FERNÁNDEZ, O. Differential effect of the route of inoculation of rabies virus on NeuN immunoreactivity in the cerebral cortex of mice. Int. J. Morphol., 34(4):1362-1368, 2016.

SUMMARY: Rabies is a lethal disease caused by a neurotropic virus that produces inconspicuous morphological changes hardly observable with conventional histopathology. The fatal outcome caused by rabies could be attributed to specific biochemical changes that severely impact neuronal function. The neuronal nuclear protein (NeuN) has become a widely used neuronal marker for the research and the histopathological diagnosis of nervous system diseases. To evaluate the distribution of the protein NeuN in the motor cortex of normal and rabies-infected mice adult ICR mice were inoculated with rabies virus either intramuscularly or intracerebrally. Rabies-infected mice were sacrificed at the terminal stage of the disease. Control mice were also euthanized at the same age. The brains were removed and cut into coronal sections on a vibratome. Immunohistochemistry was used to study the expression of NeuN in the motor area of the cerebral cortex. Neuronal counts, cellular optical densitometry and neuronal diameter measurements were performed to analyze the immunoreactivity of the protein. All parameters revealed decreased immunoreactivity for NeuN in cortical neurons of mice intracerebrally infected with rabies. In contrast, the changes were not statistically significant in mice inoculated intramuscularly. Either the immunoreactivity of NeuN or its expression is affected by the presence of rabies virus in the cerebral cortex depending on the inoculation route. These results contribute to the knowledge of the dynamics of cellular infection on rabies pathogenesis.

KEY WORDS: Rabies; NeuN; Cerebral cortex; Mouse; Immunohistochemistry; Neurons.

\section{INTRODUCTION}

Rabies remains a public health problem in developing countries. Rabies can be prevented by the vaccination of pets and people at high risk of contact with the virus. The entire population is not vaccinated because of the high cost associated with the vaccine and other factors. In addition, it is almost impossible to eradicate a virus that has wild vectors. Despite the availability of preventive controls, there are still approximately 55.000 deaths reported yearly due to rabies worldwide. The destruction of natural habitats and climate change are factors that cause vector displacement to areas that are inhabited by humans and domestic animals, increasing the risk of disease transmission (WHO, 2013).

The rabies virus spreads through retrograde axonal transport from the bite of an infected animal. Once the virus enters into the nerve terminals of the new host, it is transported to the motor neurons of the spinal cord and advances to the brain, causing marked neuronal dysfunction with fatal results. Despite the severity of clinical symptoms, rabies produces only a low inflammatory and microglial reaction in the nervous tissue. Only small brain abnormalities and the presence of eosinophilic cytoplasmic inclusions called Negri bodies are observed with conventional anatomical and histopathological analysis methods. Negri bodies are formed by a granular matrix surrounded by viral particles (Iwasaki \& Tobita, 2002).

Rabies does not appear to induce massive neuronal loss. However, in some experimental studies that have been performed, apoptosis were reported in some neurons principally when the virus was inoculated intracerebrally (Jackson \& Fu, 2013). Therefore, it is important to perform studies about the dynamics of cellular infection using alternative tools as the neuronal markers. These molecules

\footnotetext{
* Grupo de Morfología Celular, Instituto Nacional de Salud (INS), Bogotá, Colombia.

This work was funded by Departamento Administrativo de Ciencia, Tecnología e Innovación COLCIENCIAS and Instituto Nacional de Salud (INS, Colombia). Code of Grant 210465740573, Contract 639/2014.
} 
have allowed evaluating parameters as changes in the structure, number and distribution of neurons in the cerebral cortex of rabies-infected mice. (Torres-Fernández et al., 2004; Torres-Fernández et al., 2005; Rengifo \& TorresFernández, 2007; Hurtado et al., 2015).

The neuronal nuclear protein (NeuN) has become a widely used neuronal marker for the histopathological diagnosis of nervous system diseases and for research on embryonic development, adult neurogenesis and neuronal loss studies in natural and experimental conditions (Wolf et al., 1996; Sarnat et al., 1998; Gittins \& Harrison, 2004; Yang et al., 2011). These features make this protein an excellent marker for the study of neurological diseases that induce morphological changes that are difficult to detect, such as rabies disease. However we don't know previous studies about NeuN in rabies. The distribution of NeuN in the cerebral cortex of mice under normal conditions and the NeuN immunoreactivity in rabies-infected mice was assessed in this work. In addition, the effects of two different pathogen inoculation routes were compared to contribute knowledge about rabies pathogenesis.

\section{MATERIAL AND METHOD}

Laboratory animals and viral inoculation. A total of 20 female ICR (Institute of Cancer Research) mice at 28 days old were used. Mice were maintained in the animal facility of the National Institute of Health (Instituto Nacional de Salud, INS) in the high-security area under environmental and nutritional conditions in accordance with the ethical and legal standards required for animal laboratory research approved by the Ethics Committee of the INS and Colombian law (Law 86 of 1989 and resolution No. 008430 of 1993 of the Ministry of Health). Two groups of 5 mice were inoculated with $0.03 \mathrm{ml}$ (each animal) of a solution of the challenge virus standard (CVS) strain of rabies virus by two different infection routes. The first group was inoculated intramuscularly with a viral dilution of $10^{9.1}$ (LD50), and the second group was inoculated intracerebrally with a dilution of $10^{4.1}$ (LD50). For each group of infected animals, an equivalent number of control animals inoculated under the same conditions with only the viral carrier (virus-free solution containing $2 \%$ standard horse serum and the antibiotics penicillin and streptomycin at $200 \mathrm{UI} / \mathrm{ml}$ and 4 $\mathrm{mg} / \mathrm{ml}$, respectively) was used.

Procedure to obtain brain tissue sections. Mice showing signs associated with the rabies terminal phase were selected. Signs were observed for approximately 5 to 7 days after inoculation. Animals were anesthetized by injecting $0.2 \mathrm{ml}$ of $30 \%$ chloral hydrate intraperitoneally $(350 \mathrm{mg} / \mathrm{kg})$. The animals were then fixed by intracardiac perfusion first with phosphate buffered saline (PBS) solution at $\mathrm{pH} 7.3$ for 5 minutes and then with a $4 \%$ paraformaldehyde fixative solution prepared in phosphate buffer $(70 \mathrm{ml}$ of solution for 10 minutes). PBS was allowed to circulate again for one minute after perfusion when the fixation was complete. Brains were carefully extracted and were immersed in the same fixing solution that was used for perfusion. Samples were maintained at $4{ }^{\circ} \mathrm{C}$ for a minimum of 20 hours up to two weeks before processing for immunohistochemistry.

Hemispheres were separated, and tissue slices with a maximum thickness of $1 \mathrm{~cm}$ were obtained from each. Slices were made on the coronal plane from a tissue brain fragment between the corpus callosum knee and the dorsal fornix; this area mainly covers the motor cortex according to the Valverde's mouse atlas (Valverde, 1998). These tissue blocks were placed on a vibratome to obtain $50-\mu \mathrm{m}$-thick coronal sections that were then transferred to small circular glass boxes with a $1.5 \mathrm{~cm}$ radius containing PBS. In each case, the sections were placed and allowed to stir (in a horizontal shaker-rotator) at room temperature $\left(20^{\circ} \mathrm{C}\right)$ overnight.

Immunohistochemistry protocol. The sections were processed in suspension during all stages of the immunohistochemical protocol to detect NeuN and with constant stirring at room temperature $\left(20^{\circ} \mathrm{C}\right)$. PBS at $\mathrm{pH}$ 7.3 was used for the initial wash and for all washes after each stage of the process. After the first wash, the sections were treated with $0.05 \mathrm{M}$ ammonium chloride to counteract the effect of aldehydes and with $3 \%$ hydrogen peroxide to inactivate endogenous peroxidases. The sections were then incubated in normal horse serum and bovine serum albumin.

Three different dilutions of the primary antibody (monoclonal anti-NeuN from Chemicon-Millipore; Germany, Darmstadt) were tested: 1:625, 1:1250 and 1:2500. Incubation with primary antibody was performed overnight (20 hours) due to the thickness of the sections. The next day, after washing with PBS, sections were incubated with the secondary antibody (biotinylated polyclonal anti-mouse IgG from Sigma) for two hours. Two dilutions of the secondary antibody were tested, 1:400 and 1:600, which were prepared in PBS. After washing, the sections were treated with $\mathrm{ABC}$ Vector ${ }^{\circledR}$ solution (avidinbiotin complex) for two hours. Then, the immunostain were developed using a solution of the diaminobenzidine (DAB) chromogen. Different developing times were tested. Sections were rapidly washed with distilled water and then with PBS to end the reaction. Finally, sections were extended on $1 \%$ gelatin-pretreated glass slides, air dried and mounted with Entellan ${ }^{\circledR}$. 
Histological and digital image analysis. Initially, qualitative observations of immunohistochemical preparations obtained from control animals were performed to determine the presence of NeuN-immunoreactive (NeuN+) cells and to observe the distribution of NeuN under normal conditions. The same procedure was applied to samples taken from groups of animals inoculated with rabies virus. Panoramic and detailed pictures of histological sections of normal and infected samples were taken to perform quantitative analysis. Three neuron counts from the motor cortex of each sample from control and virusinfected animals were performed using a Zeiss-Netzmiier microscope with a $1 \mathrm{~mm}^{2}$ mesh in 10x fields to locate the area of the frontal cortex. Counts were made through all cortical layers of the motor area.

Images of the cerebral cortex from control and infected samples were digitized, and cellular optical densitometry was performed using Q-Capture Pro software. Cerebral cortex images were captured in 40x fields (three sections per sample). Subsequently, the Image J program was used to quantify protein immunostaining, and diameter measurements (in micrometers) were performed in $\mathrm{NeuN}+$ cells with Q-Capture Software following similar protocols to those we published previously. The quantitative analysis was performed on 5 samples of infected animals and their respective controls for each study group. The statistical Wilcoxon-Mann-Whitney test (nonparametric) suitable for a small number of high-variability samples was used (Torres-Fernández et al., 2004; Rengifo \& Torres-Fernández).
The effect of rabies virus on the number of NeuN+ cortical neurons. A panoramic view of the microscopically observed histological preparations showed decreased staining of NeuN+ cells in the cerebral cortex of infected animals (Figs. 1b and 1d); in contrast, a loss in the number of NeuN+ neurons was not evident. However, it was found that infection with rabies by either of the two routes of infection decreased the total number of NeuN+ cells in the inoculated animals, but this decrease was only statistically significant for the group inoculated intracerebrally.

The number of neurons NeuN+ was $1754 \pm 69$ in the control group and $1568 \pm 72$ in the group infected intracerebrally $(p=0.0317)$ (Table I). In the group infected intramuscularly, the number of neurons $\mathrm{NeuN}+$ was $1407 \pm$ 144 , whereas in controls, it was $1458 \pm 172(\mathrm{p}=0.7937)$ (Table II). The loss of neurons $(\mathrm{NeuN}+$ ) was more pronounced in cortical layer $\mathrm{V}$ of animals inoculated intracerebrally, especially in cortical layer $\mathrm{Vc}(\mathrm{p}=0.008)$ (Table I, Figs. 1d and 2b), whereas the difference was not statistically significant for any of the cortical layers in animals inoculated intramuscularly (Table II).

Optical densitometry and NeuN+ cell size. A loss of immunostaining was observed in all cortical layers and especially in layer V (Figs. 1 and 2). The optical densitometry analysis showed decreased cell immunolabeling was only statistically significant for the tissues of animals inoculated

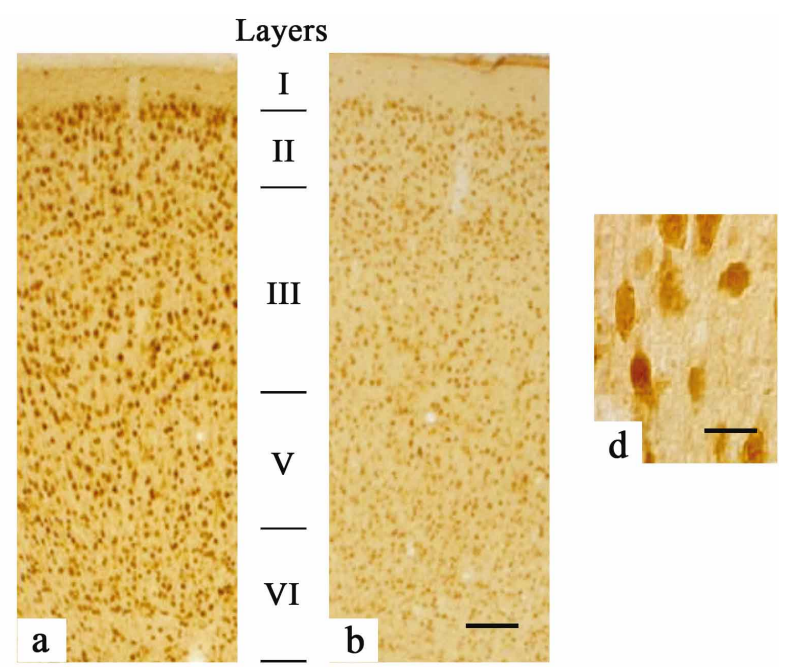

\section{Distribution of neurons immunoreactive for NeuN in the cortex of normal mice. Antibody dilutions for the best obtained immunostaining} were 1:1250 for the primary antibody and 1:400 for the secondary antibody. NeuN+ neurons were observed in all cortical layers with an apparently uniform distribution, except for layer I, where a small number of $\mathrm{NeuN}+$ neurons (Figs. 1a and 2a) was noted. However, the counts performed on each of the layers of the cortex showed a higher concentration of immunoreactive cells in layers III, V and VI in all groups of animals. The morphology exhibited by labeled neurons revealed highly homogeneous cell bodies and no labeling of cellular processes (dendrites) (Fig. 1c).

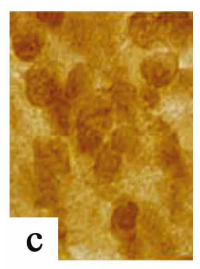

Fig. 1. Distribution of NeuN immunoreactivity in the cerebral cortex of mice. (a) Panoramic view of the cerebral motor cortex of a control mouse showing NeuN labeling. (b) Panoramic view of the cerebral cortex of a rabies-infected mouse inoculated intracerebrally. Note the decrease in NeuN immunoreactivity. (c) Magnification of layer V from the image in (a), where a high density of neurons with strong staining is observed. (d) Magnification of layer $\mathrm{V}$ of the image in (b) shows the lower cell density. Layer IV is not included in this picture because this layer is thought to be absent in the agranular motor cortex (Valverde, 1998). DAB stain. Scale bar, $60 \mu \mathrm{m}$ (figs. a y b); scale bar, $15 \mu \mathrm{m}$ (figs. c y d). 

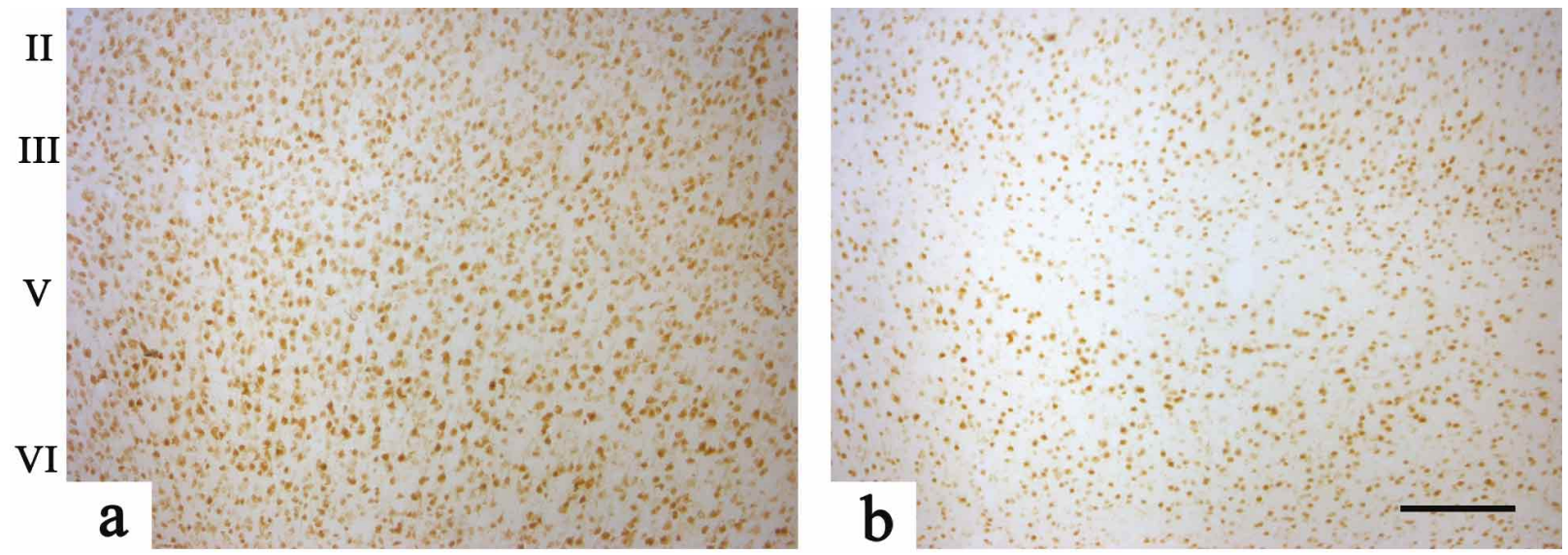

Fig. 2. Distribution of NeuN immunoreactivity in the mouse cortex. (a) NeuN+ cells in a sample of the motor cortex from a control mouse; note the strong staining through all cortical layers. (b) NeuN+ cells in the motor cortex of a mouse inoculated with rabies virus intracerebrally; note the decreased staining, especially in layer V. The loss of NeuN-immunoreactive neurons is evident, and the immunostaining also exhibits a lower intensity. DAB stain. Scale bar, $200 \mu \mathrm{m}$.

Table I. Distribution of the number of NeuN+ cells observed in a 1-mm cortical column in different layers of the motor area. Mice intracerebrally inoculated with rabies virus and their controls. For each sample, the mean of the number of neurons per layer is given.

\begin{tabular}{|c|c|c|c|c|c|c|c|c|c|c|c|c|c|}
\hline \multirow[t]{2}{*}{ Layer } & \multicolumn{5}{|c|}{ Control samples } & \multirow{2}{*}{$\begin{array}{c}\text { Mean \# of cells per } \\
\text { layer }\end{array}$} & \multicolumn{5}{|c|}{ Infected samples } & \multirow[t]{2}{*}{$\begin{array}{c}\text { Mean \# of cells per } \\
\text { layer }\end{array}$} & \multirow[t]{2}{*}{ p value } \\
\hline & 1 & 2 & 3 & 4 & 5 & & 1 & 2 & 3 & 4 & 5 & & \\
\hline I & 21 & 32 & 16 & 26 & 19 & $23 \pm 6$ & 24 & 19 & 13 & 28 & 26 & $22 \pm 6$ & 0.999 \\
\hline II & 149 & 162 & 136 & 135 & 158 & $148 \pm 12$ & 138 & 115 & 134 & 135 & 137 & $132 \pm 10$ & 0.111 \\
\hline III & 430 & 444 & 468 & 459 & 475 & $455 \pm 18$ & 429 & 474 & 486 & 464 & 449 & $460 \pm 22$ & 0.310 \\
\hline $\mathbf{V a}$ & 146 & 143 & 101 & 138 & 123 & $130 \pm 19$ & 106 & 99 & 98 & 99 & 131 & $107 \pm 14$ & \\
\hline $\mathbf{V b}$ & 134 & 121 & 108 & 143 & 133 & $128 \pm 14$ & 115 & 106 & 113 & 96 & 114 & $109 \pm 8$ & 0.056 \\
\hline $\mathrm{Ve}$ & 131 & 126 & 118 & 159 & 151 & $137 \pm 17$ & 108 & 104 & 112 & 110 & 114 & $110 \pm 4$ & \\
\hline Vd & 146 & 127 & 125 & 162 & 171 & $146 \pm 21$ & 113 & 112 & 105 & 113 & 137 & $116 \pm 12$ & \\
\hline VIa & 151 & 124 & 142 & 170 & 184 & $154 \pm 23$ & 116 & 118 & 101 & 142 & 161 & $128 \pm 24$ & 0.111 \\
\hline VIb & 176 & 140 & 148 & 162 & 112 & $148 \pm 24$ & 136 & 126 & 118 & 144 & 153 & $135 \pm 14$ & 0.421 \\
\hline VIc & 170 & 138 & 132 & 114 & 119 & $135 \pm 22$ & 119 & 108 & 118 & 124 & 119 & $118 \pm 6$ & 0.222 \\
\hline VId & 156 & 167 & 153 & 122 & 156 & $151 \pm 17$ & 121 & 132 & 130 & 137 & 143 & $133 \pm 8$ & 0.087 \\
\hline Total & 1810 & 1724 & 1647 & 1790 & 1801 & $1754 \pm 69$ & 1525 & 1513 & 1528 & 1592 & 1684 & $1568 \pm 72$ & $0.0317^{* *}$ \\
\hline
\end{tabular}

$(* *)$ Statistically significant; $( \pm)$ Standard deviation.

Table II. Distribution of the number of NeuN+ cells observed in a $1 \mathrm{~mm}$ cortical column in different layers of the motor area. Mice intramuscularly inoculated with rabies virus and their controls. In each sample, the mean of the number of neurons per layer is given.

\begin{tabular}{|c|c|c|c|c|c|c|c|c|c|c|c|c|c|}
\hline \multirow[t]{2}{*}{ Layer } & \multicolumn{5}{|c|}{ Control samples } & \multirow[t]{2}{*}{$\begin{array}{c}\text { Mean \# of cells } \\
\text { per layer }\end{array}$} & \multicolumn{5}{|c|}{ Infected samples } & \multirow[t]{2}{*}{$\begin{array}{c}\text { Mean \# of cells } \\
\text { per layer }\end{array}$} & \multirow[t]{2}{*}{$\underset{\text { value }}{p}$} \\
\hline & 1 & 2 & 3 & 4 & 5 & & 1 & 2 & 3 & 4 & 5 & & \\
\hline $\mathbf{I}$ & 17 & 16 & 59 & 13 & 19 & $25 \pm 19$ & 24 & 28 & 15 & 16 & 22 & $21 \pm 5$ & 0.7381 \\
\hline II & 108 & 94 & 156 & 118 & 117 & $119 \pm 23$ & 142 & 140 & 122 & 142 & 137 & $137 \pm 8$ & 0.1349 \\
\hline III & 322 & 332 & 329 & 377 & 321 & $336 \pm 23$ & 373 & 339 & 330 & 313 & 344 & $340 \pm 22$ & 0.6905 \\
\hline $\mathbf{V a}$ & 100 & 106 & 140 & 110 & 86 & $108 \pm 20$ & 134 & 105 & 88 & 88 & 102 & $103 \pm 19$ & 0.6508 \\
\hline $\mathbf{V b}$ & 99 & 95 & 140 & 117 & 100 & $110 \pm 19$ & 123 & 105 & 84 & 89 & 110 & $102 \pm 16$ & 0.6905 \\
\hline Ve & 111 & 120 & 145 & 127 & 114 & $123 \pm 14$ & 134 & 95 & 90 & 97 & 101 & $103 \pm 18$ & 0.0952 \\
\hline Vd & 141 & 130 & 153 & 156 & 141 & $144 \pm 10$ & 156 & 100 & 95 & 136 & 134 & $124 \pm 26$ & 0.2302 \\
\hline VIa & 140 & 140 & 164 & 158 & 147 & $150 \pm 11$ & 158 & 93 & 98 & 137 & 138 & $125 \pm 28$ & 0.0714 \\
\hline VIb & 132 & 80 & 147 & 142 & 101 & $120 \pm 29$ & 124 & 102 & 111 & 150 & 134 & $124 \pm 19$ & 0.8413 \\
\hline VIc & 106 & 120 & 166 & 94 & 100 & $117 \pm 29$ & 116 & 117 & 118 & 114 & 112 & $115 \pm 2$ & 0.6905 \\
\hline VId & 114 & 95 & 136 & 101 & 80 & $105 \pm 21$ & 151 & 129 & 96 & 83 & 103 & $112 \pm 27$ & 0.6905 \\
\hline Total & 1390 & 1328 & 1735 & 1513 & 1326 & $1458 \pm 172$ & 1635 & 1353 & 1247 & 1365 & 1437 & $1407 \pm 144$ & 0.7937 \\
\hline
\end{tabular}


intracerebrally ( $\mathrm{p}=0.0079)$ (Table III), whereas in mice inoculated intramuscularly, the difference was not statistically significant. These results are consistent with the observed neuronal counts. In addition, a decreasing trend in the size of the neurons profiles in both groups of infected animals was found after measuring the diameter of NeuN-immunoreactive neurons (intracerebral, $\mathrm{p}=0.0317$; intramuscular, $\mathrm{p}=0.0546)$ (Table IV).

Table III. Optical densitometry of NeuN immunoreactivity per cell in cerebral cortex from mice inoculated with rabies virus intracerebrally or intramuscularly. Each value corresponds to the mean of the reading of 20 cells. Reading scale (0-255 grey levels); the higher the value, greater light transmittance and, lower optical density, therefore lower immunoreactivity. Measurements at 40X.

\begin{tabular}{|c|c|c|c|c|}
\hline \multirow{2}{*}{ Sample } & \multicolumn{2}{|c|}{$\begin{array}{c}\text { Optical density. } \\
\text { Mice inoculated intracerebrally }\end{array}$} & \multicolumn{2}{|c|}{$\begin{array}{l}\text { Optical density. } \\
\text { Mice inoculated intramuscularly }\end{array}$} \\
\hline & Controls & Infected & Controls & Infected \\
\hline 1 & $104.12 \pm 12.99$ & $125.65 \pm 6.73$ & $117.17 \pm 5.68$ & $97.08 \pm 9.94$ \\
\hline 2 & $108.38 \pm 1$ & $127.67 \pm 13.17$ & $101.51 \pm 5.95$ & $114.04 \pm 12.19$ \\
\hline 3 & $106.11 \pm 10.58$ & $127.62 \pm 6.20$ & $97.92 \pm 5.56$ & $122.61 \pm 1.75$ \\
\hline 4 & $114.07 \pm 3$ & $127.77 \pm 2.11$ & $11.95 \pm 4.46$ & $109.19 \pm 12.56$ \\
\hline 5 & $112.54 \pm 2.52$ & $125.43 \pm 8.76$ & $103.80 \pm 3.19$ & $102.15 \pm 9.68$ \\
\hline Me & $\begin{array}{r}109.05 \pm 4.21 \\
p=\end{array}$ & $\underset{79 * *}{126.83} \pm 1.18$ & $106.47 \pm 7.90$ & $\begin{array}{l}109.01 \pm 10.0 \\
9413\end{array}$ \\
\hline
\end{tabular}

(**) Statistically significant; ( \pm ) Standard deviation.

Table IV. Diameter (in micrometers) of NeuN+ cells in cerebral cortex of mice inoculated with rabies virus by intracerebral or intramuscular route and their controls. Each value corresponds to the mean of 20 cells per section in three sections. Measurements were performed with a 40X objective.

\begin{tabular}{ccccc}
\hline \multirow{2}{*}{ Sample } & \multicolumn{2}{c}{$\begin{array}{c}\text { Diameter of NeuN+ cells. } \\
\text { Mice inoculated intracerebrally }\end{array}$} & \multicolumn{2}{c}{$\begin{array}{c}\text { Diameter of NeuN+cells. } \\
\text { Mice inoculated intramuscularly }\end{array}$} \\
\cline { 2 - 5 } & Controls & Infected & Controls & Infected \\
\hline $\mathbf{1}$ & $10.92 \pm 0.08$ & $8.70 \pm 0.38$ & $10.39 \pm 0.38$ & $7.91 \pm 0.63$ \\
$\mathbf{2}$ & $12.35 \pm 0.19$ & $9.80 \pm 0.61$ & $9.42 \pm 1.50$ & $7.44 \pm 0.05$ \\
$\mathbf{3}$ & $12.17 \pm 0.21$ & $10.78 \pm 1.20$ & $10.57 \pm 0.40$ & $8.72 \pm 0.37$ \\
$\mathbf{4}$ & $10.26 \pm 2.39$ & $9.93 \pm 0.10$ & $9.66 \pm 2.09$ & $10.11 \pm 2.06$ \\
$\mathbf{5}$ & $10.38 \pm 0.19$ & $9.36 \pm 0.10$ & $9.53 \pm 0.88$ & $8.77 \pm 0.05$ \\
& & & & \\
Mean & $\mathbf{1 1 . 2 1} \pm \mathbf{0 . 1 0}$ & $\mathbf{9 . 7 1} \pm \mathbf{0 . 7 6}$ & $\mathbf{9 . 9 2} \pm \mathbf{0 . 5 3}$ & $\mathbf{8 . 5 9} \pm \mathbf{1 . 0 2}$ \\
& $\boldsymbol{p}=\mathbf{0 . 0 3 1 7 * *}$ & $\boldsymbol{p}=\mathbf{0 . 0 5 4 6}$ \\
\hline
\end{tabular}

(**) Statistically significant; \pm Standard deviation.

\section{DISCUSSION}

Standardization of dilutions for NeuN immunohistochemistry. In reviewing the literature, there was no consistent correlation between the methods used and the dilution of anti-NeuN antibody chosen in each case. In the original reference describing NeuN, protein samples were embedded in plastic resin, and the dilution used was 1:100 (Mullen et al., 1992). In most cases, nervous tissue samples were processed by paraffin embedding, and the dilutions used were very diverse: 1: 100 (Gittins \& Harrison), 1:500 (Wolf et al.; Unal-Cevik et al., 2004; Collombet et al., 2006), 1:1000 (Gill et al., 2005), 1:1500 (Sarnat et al.) and 1:2000 (Salamon et al., 2006). Additionally, the work performed on sections obtained by cryotomy (sections from frozen tissue), which better preserves the immunoreactivity of antigens, reported dilutions ranging from 1:100 to 1:5000 (Jongen-Rêlo \& Feldon, 2002; Lee et al., 2003; McPhail et al., 2004; Yang et al.). Sections obtained with the vibratome used in this study are also suitable for good preservation of antigens; however, there are few previous reports of using vibratome sections for the study of NeuN (Escobar et al., 2008; Torres-Fernández et al., 2008), in these studies, a dilution of 1:2500 was reported. The variability in the dilutions cannot be explained by the origin of the antibodies because most studies were performed with a single commercially available antibody; only in recent years have we seen anti-NeuN antibodies available from other brands. Given the above information, it was necessary to perform the assays that led us to establish the dilution of 1:1250 as that with which the best results were observed. The selection criterion was to obtain good labelling of neuronal cell bodies and lower nonspecific background staining.

Distribution of NeuN+ neurons in the normal mouse cortex. The results of this study are consistent with our previous study (Torres-Fernández et al., 2008) in which NeuN+ neurons were observed to be uniformly distributed in dense layers thorough the mouse cortex, except for in layer I, where there were only a small number of neurons. This distribution of $\mathrm{NeuN}+$ neurons in the cortex of mice is similar to that observed in other studies conducted on mice (Unal-Cevik et al.) and rats (Jongen-Rêlo \& Feldon) and in the human cerebral cortex (Escobar $e t$ al.). The shortage of NeuN+ neurons in layer I of the cortex simply reflects the known fact that this layer has few 
neurons. There are two types of neurons in cortical layer I: Cajal horizontal cells (also called Cajal-Retzius) and other types of smaller neurons (Marín-Padilla, 1998). Some authors have described the lack of NeuN staining in Cajal-Retzius cells. However, in this work and in our previous work the presence of NeuN+ cells in layer I was evident. The results are similar to those reported in mice, rats and humans (Unal-Cevik et al.; Jongen-Rêlo \& Feldon; Escobar et al.). Moreover, these cells are also immunoreactive for the protein calretinin (DeFelipe, 1997). In a previous study, we found the presence of calretinin immunoreactive cells in layer I of the mouse cortex (TorresFernández et al., 2004), and its distribution was highly similar to that observed for NeuN immunostaining. Therefore, at least for the mouse cerebral cortex, cells of the molecular layer (layer I) have both neuronal markers, i.e., NeuN and calretinin.

Effect of rabies virus on NeuN immunoreactivity in mouse cortical neurons. Infection by intracerebral inoculation of rabies virus decreased $\mathrm{NeuN}$ immunoreactivity in the cerebral cortex of mice, as established by fewer NeuN+ cells as well as a decrease in immunostaining calculated by optical densitometry and the size in the profile of neurons. Whether this may be related to neuronal death or whether infection with rabies virus affects the expression of the protein or only its immunoreactivity is still undefined. The use of NeuN immunohistochemistry in studies that require neuronal counts is the more reliable alternative to the traditional method based on Nissl staining with cresyl violet or thionine because NeuN more readily distinguishes between small neurons and glia (Gittins \& Harrison). However, the usefulness of $\mathrm{NeuN}$ staining was interrogated for this purpose in a study which showed loss of immunoreactivity of the protein, but no neuronal death (Unal-Cevik et al.). A subsequent investigation criticized this earlier study and supported the usefulness of NeuN for neuronal counts, suggesting that a reasonable time should elapse before the effect of a disease on a neuronal population was assessed (Collombet et al.).

The loss of NeuN immunoreactivity induced by rabies virus intracerebral inoculation could occur because this type of experimental infection in mice induces neuronal death by apoptosis (Jackson \& Fu). However, studies that correlate neuronal count with Nissl staining, quantify neuronal death by apoptosis and label cells with NeuN are needed to definitively establish whether this protein is a good marker for studies of rabies-induced neuronal loss in different areas of the nervous system. Moreover, no loss in the number of $\mathrm{NeuN}+$ cells in the cortex of animals intramuscularly inoculated with rabies virus was found. This observation could indicate that in this condition, there is no neuronal death and no effect on protein expression. We should keep in mind that this experimental model more closely simulates what happens during natural infection. It has been established in rabies infections of both humans and other animals that under natural conditions, this viral infection does not induce neuronal death by apoptosis (Jackson et al., 2008; Suja et al., 2011). Similarly, apoptosis was not observed in mice intramuscularly inoculated with rabies virus except in special experimental conditions (Jackson \& Fu).

The decrease of NeuN+ immunoreactivity in layer $\mathrm{V}$ was more dramatic in animals inoculated intracerebrally. Studies on other diseases have reported similar effects on pyramidal neurons. In patients with head trauma, a decrease in NeuN+ neurons was found in cortical layers III and V (Escobar et al.). This susceptibility may occur because the pyramidal cells in layers III and V are part of large interconnected networks with other areas of the nervous system (DeFelipe). Finally, the susceptibility of pyramidal neurons to rabies infection has also been demonstrated in other studies we have conducted (Hurtado et al.). On the other hand, the difference in NeuN immunoreactivity in animals infected by both routes of inoculation confirms that it is necessary to interpret with caution the findings obtained in experiments with rabies where the intracerebral inoculation route was used. The results obtained by intramuscular infection with rabies better reflect the natural conditions of the disease and thus offer more realistic approaches to understanding the physiopathological mechanisms of this viral disease.

ACKNOWLEDGEMENTS. We thank to our colleague Jorge Alonso Rivera for advice and support in the processing and presentation of images.

RENGIFO, A. C.; UMBARILA, V. J.; GARZÓN, M. J. \& TORRESFERNÁNDEZ, O. Efecto diferencial de la vía de inoculación del virus de la rabia sobre la inmunorreactividad de NeuN en la corteza cerebral de ratones. Int. J. Morphol., 34(4):1362-1368, 2016.

RESUMEN: La rabia es una enfermedad mortal causada por un virus neurotrópico que produce discretos cambios morfológicos difícilmente observables con la histopatología convencional. El desenlace fatal causado por la rabia puede atribuirse a cambios bioquímicos específicos que afectan gravemente la función neuronal. La proteína nuclear neuronal (NeuN) es un marcador ampliamente utilizado para la investigación y el diagnóstico histopatológico de enfermedades del sistema nervioso. Este trabajo se realizó con el propósito de evaluar la distribución de la proteína NeuN en la corteza motora de ratones normales y ratones infectados con virus de la rabia. Ratones ICR adultos fueron inoculados con virus de la rabia por vía intramuscular o por vía intracerebral. Los animales infectados con rabia fueron sacrificados en la etapa terminal de la enfermedad. Ratones de la misma edad no inoculados con el virus (controles) fueron sacrificados simultáneamente. Se extrajeron los cerebros y se obtuvieron cortes coronales en un vibrátomo. Mediante inmunohistoquímica se estudió la expresión de NeuN en el área motora de la corteza cerebral. Se realizaron conteos neuronales, densitometría óptica celular y mediciones del diámetro de los perfiles neuronales para analizar la inmunorreactividad de la proteína. En los ratones inoculados por vía intracerebral hubo disminución significativa de la inmunorreactividad de NeuN manifestada en los diferentes parámetros 
evaluados. En contraste, estos cambios no fueron estadísticamente significativos en los cerebros de ratones inoculados por la ruta intramuscular. La inmunorreactividad de NeuN o su expresión es afectada por la presencia del virus de la rabia en la corteza cerebral pero dependiendo de la vía de inoculación. Estos resultados contribuyen al conocimiento de las dinámicas de infección celular en la patogénesis de la rabia.

PALABRAS CLAVE: Rabia; NeuN; Corteza cerebral; Ratón; Inmunohistoquímica; neuronas.

\section{REFERENCES}

Collombet, J. M.; Masqueliez, C.; Four, E.; Burckhart, M. F.; Bernabé, D.; Baubichon, D. \& Lallement, G. Early reduction of NeuN antigenicity induced by soman poisoning in mice can be used to predict delayed neuronal degeneration in the hippocampus. Neurosci. Lett., 398(3):337-42, 2006.

DeFelipe, J. Types of neurons, synaptic connections and chemical characteristics of cells immunoreactive for calbindin-D28K, parvalbumin and calretinin in the neocortex. J. Chem. Neuroanat., 14(1):1-19, 1997.

Escobar, M. I.; Guzmán, F.; Buriticá, E.; Riascos, D.; Villamil, L. \& Pimienta, H. Alteración de la organización laminar y de la dendroarquitectura de la corteza cerebral del humano post-trauma craneoencefálico. Colomb. Med., 39(3 Supl. 3):51-9, 2008.

Gill, S. K.; Ishak, M. \& Rylett, R. J. Exposure of nuclear antigens in formalinfixed, paraffin-embedded necropsy human spinal cord tissue: detection of NeuN. J. Neurosci. Methods, 148(1):26-35, 2005.

Gittins, R. \& Harrison, P. J. Neuronal density, size and shape in the human anterior cingulate cortex: a comparison of Nissl and NeuN staining. Brain Res. Bull., 63(2):155-60, 2004.

Hurtado, A. P.; Rengifo, A. C. \& Torres-Fernández, O. Immunohistochemical overexpression of MAP- 2 in the cerebral cortex of rabies-infected mice. Int. J. Morphol., 33(2):465-70, 2015.

Iwasaki, Y. \& Tobita, M. Pathology. In: Jackson, A. C. \& Wunner, H. W. (Eds.). Rabies. San Diego, Academic Press, 2002. pp.283-306.

Jackson, A. C. \& Fu, Z. F. Pathogenesis. In: Jackson, A. C. (Ed.). Rabies. San Diego, Academic Press, 2013. pp.299-349.

Jackson, A. C.; Randle, E.; Lawrance, G. \& Rossiter, J. P. Neuronal apoptosis does not play an important role in human rabies encephalitis. $J$. Neurovirol., 14(5):368-75, 2008.

Jongen-Rêlo, A. L. \& Feldon, J. Specific neuronal protein: a new tool for histological evaluation of excitotoxic lesions. Physiol. Behav., 76(45):449-56, 2002.

Lee, D. R.; Helps, S. C.; Gibbins, I. L.; Nilsson, M. \& Sims, N. R. Losses of NG2 and NeuN immunoreactivity but not astrocytic markers during early reperfusion following severe focal cerebral ischemia. Brain Res., 989(2):221-30, 2003

Marín-Padilla, M. Cajal-Retzius cells and the development of the neocortex. Trends Neurosci., 21(2):64-71, 1998.

McPhail, L. T.; McBride, C. B.; McGraw, J.; Steeves, J. D. \& Tetzlaff, W. Axotomy abolishes NeuN expression in facial but not rubrospinal neurons. Exp. Neurol., 185(1):182-90, 2004.
Mullen, R. J.; Buck, C. R. \& Smith, A. M. NeuN, a neuronal specific nuclear protein in vertebrates. Development, 116(1):201-11, 1992.

Rengifo, A. C. \& Torres-Fernández, O. Decreased number neurons expressing GABA in the cerebral cortex of rabies-infected mice. Biomedica, 27(4):548-58, 2007

Salamon, N.; Andres, M.; Chute, D. J.; Nguyen, S. T.; Chang, J. W.; Huynh, M. N.; Chandra, P. S.; Andre, V. M.; Cepeda, C.; Levine, M. S.; Leite, J. P.; Neder, L.; Vinters, H. V. \& Mathern, G. W. Contralateral hemimicrencephaly and clinical-pathological correlations in children with hemimegalencephaly. Brain, 129(Pt. 2):352-65, 2006.

Sarnat, H. B.; Nochlin, D. \& Born, D. E. Neuronal nuclear antigen (NeuN): a marker of neuronal maturation in early human fetal nervous system. Brain Dev., 20(2):88-94, 1998.

Suja, M. S.; Mahadevan, A.; Madhusudana, S. N. \& Shankar, S. K. Role of apoptosis in rabies viral encephalitis: a comparative study in mice, canine, and human brain with a review of literature. Patholog. Res. Int., 2011:374286, 2011

Torres-Fernández, O.; Lamprea, N. P. \& Santamaría, G. Expresión de la proteína nuclear neuronal NeuN en el cerebro de ratones. Rev. Asoc. Colomb. Cienc. Biol., 20(1):194-95, 2008.

Torres-Fernández, O.; Yepes, G. E.; Gómez, J. E. \& Pimienta, H. J. Effect of rabies virus infection on the expression of parvalbumin, calbindin and calretinin in mouse cerebral cortex. Biomedica, 24(1):63-78, 2004.

Torres-Fernández, O.; Yepes, G. E.; Gómez, J. E. \& Pimienta, H. J. Calbindin distribution in cortical and subcortical brain structures of normal and rabies-infected mice. Int. J. Neurosci., 115(10):1375-82, 2005.

Unal-Cevik, I.; Kilinç, M.; Gürsoy-Ozdemir, Y.; Gurer, G. \& Dalkara, T. Loss of NeuN immunoreactivity after cerebral ischemia does not indicate neuronal cell loss: a cautionary note. Brain Res., 1015(1-2):169-74, 2004.

Valverde, F. The Golgi Atlas of the Postnatal Mouse Brain. New York, Springer-Verlag, 1998.

Wolf, H. K.; Buslei, R.; Schmidt-Kastner, R.; Schmidt-Kastner, P. K.; Pietsch, T.; Wiestler, O. D. \& Blümcke, I. NeuN: a useful neuronal marker for diagnostic histopathology. J. Histochem. Cytochem., 44(10):1167-71, 1996.

World Health Organization (WHO). WHO Expert Consultation on Rabies. In: World Health Organization (WHO). Technical Report Series No. 982. Geneva, WHO Press, 2013

Yang, Y.; Fung, S. J.; Rothwell, A.; Tianmei, S. \& Weickert, C. S. Increased interstitial white matter neuron density in the dorsolateral prefrontal cortex of people with schizophrenia. Biol. Psychiatry, 69(1):63-70, 2011.

Correspondence to:

Orlando Torres-Fernández

Grupo de Morfología Celular

Instituto Nacional de Salud (INS)

Av. Calle 26 No. 51-20

Bogotá DC

COLOMBIA

Received: 11-12-2015

Accepted: 10-08-2016

Email: otorresf@ins.gov.co 